\title{
Bark and ambrosia beetles (Curculionidae: Scolytinae), their phoretic mites (Acari) and associated Geosmithia species (Ascomycota: Hypocreales) from Virgilia trees in South Africa
}

\author{
Netsai M. Machingambi ${ }^{\mathrm{a}, \mathrm{b}}$, Jolanda Roux ${ }^{\mathrm{b}}$, Léanne L. Dreyer ${ }^{\mathrm{a}, \mathrm{b}}$, Francois Roets ${ }^{\mathrm{b}, \mathrm{c}^{*}}$ \\ ${ }^{a}$ Department of Botany and Zoology, Stellenbosch University, Private Bag X1, Stellenbosch, 7602, South Africa \\ ${ }^{\mathrm{b}}$ DST/NRF Centre of Excellence in Tree Health Biotechnology (CTHB), Forestry and Agricultural Biotechnology \\ Institute (FABI), Department of Microbiology and Plant Pathology, University of Pretoria, Private Bag X20, \\ Hatfield, Pretoria, 0028, South Africa \\ ${ }^{\mathrm{c} D e p a r t m e n t}$ of Conservation Ecology and Entomology, Stellenbosch University, Private Bag X1, Stellenbosch, \\ 7602, South Africa *E-mail: fr@sun.ac.za, Telephone: +27 021808 2635, Fax: +27 0218083304
}

Running Title: Geosmithia and its associates from Virgilia

\begin{abstract}
Bark and ambrosia beetles are ecologically and economically important phloeophagous insects that often have complex symbiotic relationships with fungi and mites. These systems are greatly understudied in Africa. In the present study we identified bark and ambrosia beetles, their phoretic mites and their main fungal associates from native Virgilia trees in the Cape Floristic Region (CFR) of South Africa. In addition, we tested the ability of mites to feed on the associated fungi. Four species of scolytine beetles were collected from various Virgilia hosts and from across the CFR. All were consistently associated with various Geosmithia species, fungi known from phloeophagous beetles in many parts of the world, but not yet reported as Scolytinae associates in South Africa. Four beetle species, a single mite species and five Geosmithia species were recovered. The beetles, Hapalogenius fuscipennis, Cryphalini sp. 1 and Scolytoplatypus fasciatus were associated with a single species of Elattoma phoretic mite that commonly carried spores of Geosmithia species. Liparthrum sp. 1 did not carry phoretic mites. Similar to European studies, Geosmithia associates of beetles from Virgilia were constant over extended geographic ranges, and species that share the same host plant individual had similar Geosmithia communities. Phoretic mites were unable to feed on their Geosmithia associates, but were observed to feed on bark-beetle larvae within tunnels. This study forms the first African-centred base for ongoing global studies on the
\end{abstract}


associations between arthropods and Geosmithia species. It strengthens hypotheses that the association between Scolytinae beetles and dry-spored Geosmithia species may be more ubiquitous than commonly recognised.

Key words: Insect-fungus interactions, Hypocreomycetidae, spore vector, Fabaceae, Scolytinae

\section{Introduction}

Bark and ambrosia beetles (Curculionidae, Scolytinae) are economically and ecologically important pests of trees in urban, forest, plantation and agricultural settings (Avtzis et al. 2012; Harrington 2005; Kirisits 2004; Paine et al. 1997; Six \& Wingfield 2011), with about 225 genera and more than 6000 described species globally (Avtzis et al. 2012; Linnakoski et al. 2012). Some, like the southern pine bark beetle (SPB), Dendroctonus frontalis Zimmermann, are capable of killing healthy trees, and causes substantial financial losses (Price et al. 1992). The Redbay ambrosia beetle, Xyleborus glabratus Eichhoff, which was introduced to the southeastern USA together with a fungal associate, Raffaelea lauricola T.C. Harr., Fraedrich \& Aghayeva (Fraedrich et al. 2008; Harrington et al. 2008) is responsible for the extensive wilt and death of Redbay trees (Persea borbonia (L.) Spreng.) and other members of the Lauraceae (Harrington et al. 2008). However, many scolytine beetles attack only trees that are weakened and/or stressed, or dead (Avtzis et al. 2012; Paine et al. 1997; Raffa et al. 1993; Six \& Wingfield 2011). Despite their ecological importance in, for example, initiating nutrient cycling (Christiansen et al. 1987; Stark 1982), they have not attracted much research interest, as they seldom cause economic losses, except for those few that vector detrimental fungi (Lieutier et al. 2009).

Scolytine beetles usually have complex associations with various organisms, including fungi (Linnakoski et al. 2012; Six \& Paine 1998; Six \& Wingfield 2011; Whitney 1982), bacteria (Bridges 1984), mites (Cardoza et al. 2008; Klepzig et al. 2001; Moser et al. 1995, 2005) and nematodes (Cardoza et al. 2008; Moser et al. 2005). Those associated with ophiostomatoid fungi (e.g., species of Ceratocystis, Ophiostoma and Raffaelea) are of particular interest, as these fungi include important tree pathogens (Klepzig et al. 2001; Moser et al. 1995; Wood 1982). Microbial and scolytine relationships may be incidental or obligatory, mutualistic, commensal or antagonistic (Kolařík et al. 2008; Six 2003; Six \& Wingfield 2011). The fungi benefit by being vectored to new plant hosts (Paine et al. 1997; Six 2003; Six \& Wingfield 
2011), while some beetles and mites feed on their fungal associates (Cardoza et al. 2008; Harrington 2005; Klepzig et al. 2001; Moser et al. 1995; Six 2003; Six \& Wingfield 2011). Various other fungi in this system may, in turn, be antagonistic to the beetles (Barras 1970; Harrington \& Zambino 1990; Hofstetter et al. 2006; Klepzig et al. 2001; Six \& Wingfield 2011). In addition to fungivorous mites, other phoretic taxa can be parasitic, predatory and/or omnivorous (Klepzig et al. 2001).

Most studies on the interactions between scolytine beetles and other organisms have focussed on the ophiostomatoid fungi. However, numerous other fungal taxa may be consistently associated with these beetles. This includes the genus Geosmithia Pitt, a mitosporic ascomycete genus belonging to the Hypocreales (Hypocreomycetidae) (Houbraken et al. 2012; Kolařík et al. 2004, 2005, 2007; Ogawa et al. 1997). It currently contains 31 published species, most of which have not been formally described (Hulcr \& Dunn 2011; Kolařík \& Jankowiak 2013; Kolařík \& Kirkendall 2010; Kolařík et al. 2004, 2005, 2007, 2008). Geosmithia has a worldwide distribution (Kolařík et al. 2004, 2005, 2007; Ogawa et al. 1997), but until recently the genus was understudied. However, after it was found to be commonly associated with several scolytine beetle species, there has been a growing body of literature on these fungi (Hulcr \& Dunn 2011; Kolařík \& Jankowiak 2013; Kolařík \& Kirkendall 2010; Kolařík et al. 2004, 2005, 2007, 2008, 2011). Entomochoric adaptations are absent in Geosmithia species (Kolařík \& Kirkendall 2010; Kolařík et al. 2008). Instead, they produce hydrophobic and dry conidia that are typically air borne (Kolařík et al. 2007, 2008), and some species are sporadically also collected from other substrates such as plant debris, cereals and soil (Kolařík et al. 2004; Pitt \& Hocking 2009).

Despite being regular scolytine beetle associates, the effects of Geosmithia on the beetles still remain vague (Kolařík et al. 2007, 2008) but some probably play a role in beetle nutrition (e.g., Kolařík \& Kirkendall 2010). Phytopathogens in this genus include Geosmithia morbida M. Kolarík, E. Freeland, C. Utley \& Tisserat, which is a serious threat to black walnut trees (Juglans nigra L.) as it causes thousand cankers disease, and is dispersed by the walnut twig beetle (Pityophthorus juglandis Blackman) (Kolařík et al. 2011). Geosmithia langdonii M. Kolarík, Kubátová \& Pažoutová and G. pallida (G. Sm.) M. Kolarík, Kubátová \& Pažoutová, isolated from Scolytus intricatus (Ratz.), has the ability to inhibit root formation in Lepidium sativum L., probably due to toxin production (Čizkova et al. 2005). Geosmithia langdonii was also recently identified as both a bark-beetle associate and an endophyte of coast live oaks in California (McPherson et al. 2013). 
Recent reports indicated extensive Scolytinae beetle activity on Virgilia Pior. (Fabaceae) trees endemic to the Cape Floristic Region (CFR) of South Africa. This ornamental and ecologically important tree genus is confined to riparian vegetation, thickets, hillsides and forest margins (Palgrave 1983, 2002; Palmer \& Pitman 1972). Nothing is currently known about these beetles and their associated organisms and we, therefore, set out to identify these beetles, their phoretic mites and their associated fungal species. Specific objectives included to: (i) identify bark and ambrosia beetle species that infest Virgilia trees from a wide geographical range; (ii) identify mite species phoretic on these beetles; (iii) isolate and identify fungal taxa consistently associated with the Scolytinae beetles and their phoretic mites, and (iv) test whether mites that are phoretic on these beetles can feed on the fungi they consistently carry. This study represents one of the first to describe such a system for a natural CFR host tree across its distribution range.

\section{Materials and methods}

\subsection{Scolytine beetle and mite collection}

Bark and ambrosia beetles were collected from Virgilia populations throughout the CFR between January 2011 and December 2012 (Table 1). Where possible, five declining branches (ca. $12 \mathrm{~cm}$ diam. and $40 \mathrm{~cm}$ in length), colonised by beetles (as indicated by the presence of small bore holes), were collected from random trees per population (one branch per tree), and placed in insect emergence cages (all branches per population combined per cage) constructed from sealed cardboard boxes ( 49 x 49 x $32.6 \mathrm{~cm}$ ) fitted with two clear plastic bottles $(5.7 \mathrm{~cm}$ diameters). Emerging beetles were attracted to light penetrating through these bottles, and were thus easily collected. The total number of beetle individuals per species that emerged from these samples was counted (when below 100), or estimated to the nearest 100 individuals (using average weight) when more individuals emerged. In addition, bark and ambrosia beetles were collected aseptically, directly from galleries, on supplementary collections of bark and branches.

A Leica EZ4 microscope (Leica Microsystems (Schweiz) AG, Taiwan) was used to study the collected beetles and their gallery systems. Emerging beetles were often associated with phoretic mites, and both beetles and their phoretic mites were grouped according to morphotype. Numbers of phoretic mites per individual beetle were determined, and for the 
Table 1 - Total number of individuals of four scolytine beetle species (to nearest hundred) collected from different Virgilia tree taxa at eight localities throughout the CFR of South Africa.

\begin{tabular}{|c|c|c|c|c|c|c|}
\hline Site $^{\mathrm{a}}$ & $\begin{array}{l}\text { GPS } \\
\text { coordinates }\end{array}$ & Virgilia taxon & Cryphalini sp. 1 & $\begin{array}{l}\text { Hapalogenius } \\
\text { fuscipennis }\end{array}$ & $\begin{array}{l}\text { Liparthrum sp. } \\
1\end{array}$ & $\begin{array}{l}\text { Scolytoplatypus } \\
\text { fasciatus }\end{array}$ \\
\hline HPNBG, Betty’s Bay & $\begin{array}{l}\text { S 34' 20.893” } \\
\text { E 18' 55.519” }\end{array}$ & $\begin{array}{l}\text { V. oroboides } \\
\text { oroboides }\end{array}$ & 200 & 300 & 800 & 13 \\
\hline Jonkershoek, Stellenbosch & $\begin{array}{l}\text { S 33॰58'23.10" } \\
\text { E } \\
18^{\circ} 56^{\circ} 11.38^{\prime \prime}\end{array}$ & V. o. oroboides & & & 200 & \\
\hline KNBG, Cape Town & $\begin{array}{l}\text { S 3359'11.3" } \\
\text { E 18²5'34.4" }\end{array}$ & V. o. oroboides & 700 & 800 & & \\
\hline Table Mountain, Cape Town & $\begin{array}{l}\text { S 33ํํ'17.76" } \\
\text { E } 18^{\circ} 25^{\prime} 29.64^{\prime \prime}\end{array}$ & V. o. oroboides & 900 & 1200 & 500 & \\
\hline SMNR, Cape Town & $\begin{array}{l}\text { S } 34^{\circ} 05^{\prime} 27.89^{\prime \prime} \\
\text { E } 18^{\circ} 25^{\prime} 17.55^{\prime \prime}\end{array}$ & V. o. oroboides & 400 & 400 & 700 & \\
\hline George & $\begin{array}{l}\text { S 335'⒍07" } \\
\text { E } 22^{\circ} 33^{\prime} 11.10^{\prime \prime}\end{array}$ & V. o. ferruginea & 800 & 600 & & 1 \\
\hline Knysna & $\begin{array}{l}\text { S } 34^{\circ} 00 ' 21.44^{\prime \prime} \\
\text { E } 23^{\circ} 07^{\prime} 00.61^{\prime \prime}\end{array}$ & $V$. divaricata & 700 & 900 & 300 & \\
\hline Storms River & $\begin{array}{l}\text { S } 33^{\circ} 05^{\prime} 15.54 " \\
\text { E } 18^{\circ} 25^{\prime} 06.96^{\prime \prime}\end{array}$ & V. divaricata & 1000 & 2000 & & \\
\hline
\end{tabular}


two most common bark beetle species, phoretic mite numbers were monitored over a seven week period from placement of branches in emergence cages. Each week, the number of mites per beetle was counted on 20 bark beetle individuals of each of the two species. Normality of the mite numbers data was tested using a Shapiro-Wilk test (Shapiro \& Wilk 1965), and subsequently analysed using Kruskal-Wallis ANOVA and Median test procedures in Statistica 10 (Statsoft Corporation, USA). Significant differences are reported when $\mathrm{P} \leq$ 0.05 .

Reference specimens of each beetle species collected were stored in 100\% ethanol for later identification. Representative specimens of mites were mounted onto microscope slides (following methods of Theron et al. 2012) for later identification. Reference specimens of all beetle and mite species collected in this study were deposited in the Stellenbosch University Insect Collection (USEC), Stellenbosch, South Africa.

\subsection{Fungal isolation}

Ten individuals of each beetle and mite species collected per site (where possible) were

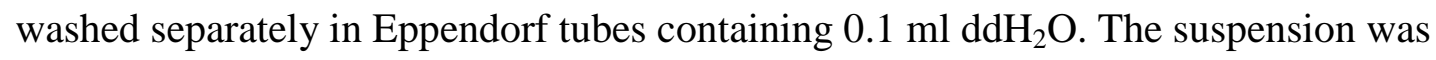
subsequently spread onto malt extract agar (MEA: 20gL-1 malt extract and 20gL-1 agar, Biolab, South Africa) in Petri dishes. An additional 10 individuals per beetle species (per site,

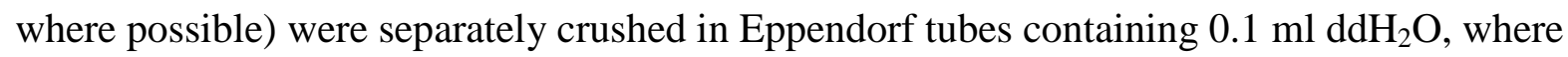
after this solution was spread onto MEA. Plates were sealed with parafilm and incubated at room temperature $\left(20\right.$ to $25^{\circ} \mathrm{C}$ ) under normal day/ night conditions until resultant fungi could be purified. Due to the large numbers of colonies of fungi originating from primary extractions, only a single representative of the most common and consistent morphotypes (see below) was chosen at random and purified. To purify the growing fungi, hyphal tips of developing mycelia were transferred to fresh MEA plates under sterile conditions.

Fungal isolations were also made directly from bark samples containing fresh beetle galleries. Bark samples were placed in separate moisture chambers (clear plastic bag with moist filter paper) for 7 to 12 days to stimulate sporulation of fungi in the gallery systems. These were stored at room temperature $\left(20\right.$ to $\left.25^{\circ} \mathrm{C}\right)$ in the dark. Spores from fungal structures that formed within galleries were transferred to MEA plates using a sterile needle and purified. Pure cultures of all isolated fungi were stored at $4^{\circ} \mathrm{C}$ on MEA until further use. 


\subsection{Fungal identification}

All fungal cultures of the most consistently isolated taxa were grouped according to morphotype based on cultural and micro-morphological characteristics following methods of Kolařík et al. (2004, 2007, 2008). A total of 75 cultures, including representatives of each morphotype, were selected for identification based on DNA sequencing. Representative isolates of all fungal morphotypes identified in this study were deposited in the culture collection (CMW) of the Forestry and Agricultural Biotechnology Institute (FABI), University of Pretoria, South Africa (Table 2).

\subsubsection{DNA extraction, amplification and sequencing}

Fungal mycelia were harvested from actively growing two-week-old cultures using a sterile scalpel. DNA was extracted using the Sigma-Aldrich ${ }^{\mathrm{TM}}$ plant PCR kit (Germany) following the manufacturer’s instructions. ITS1-f (Gardes \& Bruns 1993) and ITS4 (White et al. 1990) primers were used to amplify the nuclear ribosomal internal transcribed spacer regions (ITS1, ITS2) including the 5.8S gene of the rDNA. $20 \mu \mathrm{L}$ PCR reaction volumes consisted of $5 \mu \mathrm{L}$ REDExtract-N-Amp PCR ready mix (Sigma-Aldrich ${ }^{\mathrm{TM}}$, USA), $10 \mu \mathrm{L} \mathrm{ddH}_{2} \mathrm{O}, 0.5 \mu \mathrm{L}(10 \mathrm{mM})$ of each primer and $4 \mu \mathrm{L}$ extracted fungal DNA. PCR reaction conditions were: initial denaturation at $95^{\circ} \mathrm{C}$ for 2 minutes, followed by 35 cycles of denaturation at $95^{\circ} \mathrm{C}$ for 30 seconds, annealing at $55^{\circ} \mathrm{C}$ for 30 seconds, elongation at $72^{\circ} \mathrm{C}$ for 1 minute 30 seconds and a final elongation step at $72^{\circ} \mathrm{C}$ for 8 minutes. All PCR products were visualised by gel electrophoresis on a $1.5 \%$ agarose gel (Promega Corporation, Madison, U.S.A.) stained with $2.5 \mu \mathrm{L}$ ethidium bromide and visualised under ultraviolet light. All amplified PCR products were cleaned using the Wizard ${ }^{\circledR}$ SV gel and PCR clean-up system (Promega, Madison, Wisconsin, U.S.A.) following the manufacturer's instructions. The purified fragments were sequenced using the respective PCR primers and the Big Dye ${ }^{\mathrm{TM}}$ Terminator v3.0 cycle sequencing premix kit (Applied Biosystems, Foster City, CA, U.S.A.), and analysed on an ABI PRISIMTM 3100 Genetic Analyser (Applied Biosystems).

\subsubsection{Phylogenetic analyses}

Fungal sequences generated in this study (Table 2) were compared to published sequences for described Geosmithia species and other operational taxonomic units (OTU’s) identified in previous studies (Kolařík \& Jankowiak 2013; Kolařík \& Kirkendall 2010; Kolařík et al. 2004, 2005, 2007, 2008, 2011) available from GenBank (www.ncbi.nlm.nih.gov/genbank). The 
Table 2 - Collection details of representative isolates of Geosmithia OTU's identified and used for molecular characterisation.

\begin{tabular}{|c|c|c|c|c|c|}
\hline Geosmithia OTU $^{\mathrm{a}}$ & $\begin{array}{l}\text { Isolate } \\
\text { number }\end{array}$ & Host Virgilia taxon & Site $^{c}$ & Isolated from & $\begin{array}{l}\text { Genbank } \\
\text { Accession }\end{array}$ \\
\hline Geosmithia flava & 40726 & V. oroboides oroboides & HPNBG & Hapalogenius fuscipennis & KJ513210 \\
\hline Geosmithia flava & 40727 & V. o. oroboides & SMNR & Cryphalini sp. 1 & KJ513209 \\
\hline Geosmithia flava & 40728 & V. o. oroboides & HPNBG & H. fuscipennis & KJ513208 \\
\hline Additional collections & n. a. & $\begin{array}{l}V . \text { o. ferruginea, } V \text {. } \\
\text { divaricata }\end{array}$ & $\begin{array}{l}\text { Jonkershoek, KNBG, Table } \\
\text { Mountain, George, Knysna, } \\
\text { Storms River }\end{array}$ & Liparthrum sp. 1, Elattoma sp. 1 & n. a. \\
\hline Geosmithia sp. 2 & 40743 & V. o. oroboides & HPNBG & Cryphalini sp. 1 & KJ513232 \\
\hline Geosmithia sp. 2 & 40744 & V. o. oroboides & KNBG & Cryphalini sp. 1 & KJ513233 \\
\hline Geosmithia sp. 2 & 40745 & V. divaricata & Storms River & Cryphalini sp. 1 & KJ513211 \\
\hline Geosmithia sp. 2 & 40729 & V. divaricata & Storms River & Elattoma sp. 1 & KJ513230 \\
\hline Geosmithia sp. 2 & 40736 & V. o. ferruginea & George & Cryphalini sp. 1 & KJ513234 \\
\hline Geosmithia sp. 2 & 40737 & V. o. oroboides & HPNBG & H. fuscipennis & KJ513229 \\
\hline Geosmithia sp. 2 & 40730 & V. o. oroboides & HPNBG & H. fuscipennis & KJ513231 \\
\hline Geosmithia sp. 2 & 40738 & V. o. oroboides & HPNBG & Cryphalini sp. 1 & KJ513254 \\
\hline Geosmithia sp. 2 & 40731 & V. o. oroboides & HPNBG & Cryphalini sp. 1 & KJ513253 \\
\hline Additional collections & n. a. & $\begin{array}{l}V . \text { o. ferruginea, } V . \\
\text { divaricata }\end{array}$ & $\begin{array}{l}\text { Jonkershoek, Table Mountain, } \\
\text { SMNR, Knysna }\end{array}$ & Liparthrum sp. 1, Elattoma sp. 1 & n. a. \\
\hline
\end{tabular}




\begin{tabular}{|c|c|c|c|c|c|}
\hline Geosmithia sp. 8 & 40739 & V. o. oroboides & HPNBG & Cryphalini sp. 1 & KJ513226 \\
\hline Geosmithia sp. 8 & 40740 & V. o. oroboides & HPNBG & Cryphalini sp. 1 & KJ513227 \\
\hline Geosmithia sp. 8 & 40746 & V. o. oroboides & HPNBG & H. fuscipennis & KJ513258 \\
\hline Additional collections & n. a. & n. a. & n. a. & Elattoma sp. 1 & n. a. \\
\hline Geosmithia sp. 10 & 40733 & V. o. oroboides & HPNBG & Elattoma sp. 1 & KJ513217 \\
\hline Geosmithia sp. 10 & 40734 & V. o. oroboides & HPNBG & Liparthrum sp. 1 & KJ513215 \\
\hline Geosmithia sp. 10 & 40735 & V. o. oroboides & HPNBG & Liparthrum sp. 1 & KJ513216 \\
\hline Additional collections & n. a. & $\begin{array}{l}V . \text { o. ferruginea, } V . \\
\text { divaricata }\end{array}$ & $\begin{array}{l}\text { Jonkershoek, KNBG, Table } \\
\text { Mountain, SMNR, George, } \\
\text { Knysna, Storms River }\end{array}$ & Cryphalini sp. 1 , H. fuscipennis & n. a. \\
\hline Geosmithia sp. A & 40732 & V. o. oroboides & HPNBG & Scolytoplatypus fasciatus & KJ533336 \\
\hline Geosmithia sp. A & 40741 & V. o. oroboides & HPNBG & S. fasciatus & KJ533337 \\
\hline Geosmithia sp. A & 40742 & V. o. oroboides & HPNBG & S. fasciatus & KJ533338 \\
\hline Additional collections & n. a. & V. o. ferruginea & George & Elattoma sp. 1 & n. a. \\
\hline
\end{tabular}

${ }^{a}$ Following Kolařík \& Kirkendall (2010), Kolařík \& Jankowiak (2013) and Kolařík et al. (2004, 2005, 2007, 2008).

${ }^{\mathrm{b}}$ All isolates collected by Netsai Machingambi and deposited in the University of Pretoria Culture Collection (CMW), Pretoria, South Africa

${ }^{\mathrm{c}}$ HPNBG = Harold Porter National Botanic Garden, SMNR = Silver Mine Nature Reserve, KNBG = Kirstenbosch National Botanic Garden 
Table 3 - Percentage of individuals of four Scolytinae beetle species associated with five Geosmithia taxa from Virgilia trees throughout the CFR of South Africa.

\begin{tabular}{|c|c|c|c|c|c|c|c|c|}
\hline Site $^{\mathrm{a}}$ & Virgilia taxon & Scolytinae taxon & $\mathrm{n}$ & $\begin{array}{l}\text { Geosmithia } \\
\text { flava }\end{array}$ & $\begin{array}{l}\text { Geosmithia } \\
\text { sp. } 2\end{array}$ & $\begin{array}{l}\text { Geosmithia } \\
\text { sp. } 8\end{array}$ & $\begin{array}{l}\text { Geosmithia } \\
\text { sp. } 10\end{array}$ & $\begin{array}{l}\text { Geosmithia } \\
\text { sp. A }\end{array}$ \\
\hline \multirow[t]{3}{*}{ HPNBG, Betty’s Bay } & $\begin{array}{l}\text { V. oroboides } \\
\text { oroboides }\end{array}$ & Cryphalini sp. 1 & 20 & 45 & 20 & 20 & 15 & \\
\hline & V. o. oroboides & $\begin{array}{l}\text { Hapalogenius } \\
\text { fuscipennis }\end{array}$ & 20 & 10 & 10 & 70 & 10 & \\
\hline & V. o. oroboides & Liparthrum sp. 1 & 20 & 20 & 15 & & 65 & \\
\hline $\begin{array}{l}\text { Jonkershoek, } \\
\text { Stellenbosch }\end{array}$ & V. o. oroboides & Liparthrum sp. 1 & 20 & 35 & 55 & & 10 & \\
\hline \multirow[t]{2}{*}{ KNBG, Cape Town } & V. o. oroboides & Cryphalini sp. 1 & 20 & 20 & 65 & & 15 & \\
\hline & & H. fuscipennis & 20 & 35 & 30 & & 35 & \\
\hline $\begin{array}{l}\text { Table Mountain, Cape } \\
\text { Town }\end{array}$ & & Liparthrum sp. 1 & 20 & 15 & 85 & & & \\
\hline \multirow[t]{3}{*}{ SMNR, Cape Town } & V. o. oroboides & Cryphalini sp. 1 & 20 & 65 & 10 & & 25 & \\
\hline & & H. fuscipennis & 20 & 10 & 50 & & 40 & \\
\hline & & Liparthrum sp. 1 & 20 & 65 & 10 & & 25 & \\
\hline George & $\begin{array}{l}\text { V. o. } \\
\text { ferruginea }\end{array}$ & Cryphalini sp. 1 & 20 & 20 & 60 & & 20 & \\
\hline
\end{tabular}




\begin{tabular}{|c|c|c|c|c|c|c|}
\hline & & H. fuscipennis & 20 & 50 & 10 & 40 \\
\hline & & $\begin{array}{l}\text { Scolytoplatypus } \\
\text { fasciatus }\end{array}$ & 1 & & & \\
\hline \multirow[t]{3}{*}{ Knysna } & V. divaricata & Cryphalini sp. 1 & 20 & 15 & 15 & 70 \\
\hline & & H. fuscipennis & 20 & & 25 & 75 \\
\hline & & Liparthrum sp. 1 & 20 & 10 & 90 & \\
\hline \multirow[t]{2}{*}{ Storms River } & $V$. divaricata & Cryphalini sp. 1 & 20 & & 50 & 50 \\
\hline & & H. fuscipennis & 20 & 10 & & 90 \\
\hline
\end{tabular}


dataset (available from www.treebase.org, accession number: S15465) was aligned using Clustal W (Thompson et al. 1994) and manually adjusted in BioEdit v7. 0.5 (Hall 2005). Acremonium alternatum Link (GenBank AY566992) was chosen as outgroup taxon following Kolařík \& Jankowiak (2013). Phylogenetic analyses were conducted using MrBayes v. 3.0b4 (Ronquist \& Huelsenbeck 2003) and PAUP (Phylogenetic Analysis Using Parsimony PAUP*4.0b10) (Swofford 2002). In PAUP, a Maximum Parsimony (MP) analysis was conducted using the heuristic search option with random addition of sequences (1 000 replications), tree bisection-reconnection (TBR) and MULTREES options ON. Bootstrap support values with 1000 replications were calculated to assess the confidence of resultant nodes in the MP trees with the MULTREES option OFF and 10 random sequence additions in each of 1000 pseudo-replications. In MrBayes, a Markov Chain Monte Carlo (MCMC) approach was used, using the GTR+I+K model as selected in jModelTest 0.1.1 (Posada 2008) and Akaike information criteria (Akaike 1974). Eight million generations were run, with a sampling frequency of 100 and burn-in trees set at the first 25\%. The remaining trees were pooled into a 95\% majority consensus tree.

\subsection{Mite feeding studies}

To test the ability of phoretic mites to feed and reproduce on the fungi they were commonly associated with, 10 mite individuals were placed onto three isolates of each OTU identified in this study. Plates with sterile MEA served as control, and the experiment was replicated three times. Plates (6.4 cm diam.) with fungi that had grown to fully cover the surface of the MEA media were used in these assays to limit growth of potential contaminants. To prevent mites from escaping, plates were sealed with parafilm and placed in $15 \mathrm{~L}$ plastic containers that were half-filled with water, thus allowing the plates to float. The lid of the containers was lined with petroleum jelly before closing to prevent entry of contaminating mites and other organisms. After 40 days at $25^{\circ} \mathrm{C}$ in the dark, the number of live mites in each plate was recorded using a stereo-microscope. 


\section{Results}

\subsection{Scolytine beetles}

Four species of scolytine beetles were collected from various Virgilia taxa (Virgilia oroboides oroboides, V. o. ferruginea and V. divaricata) at eight sites, including George, Harold Porter National Botanical Gardens (HPNBG), Jonkershoek, Kirstenbosch National Botanical Gardens (KNBG), Knysna, Sivermine Nature Reserve (SMNR), Storms River and Table Mountain (Table 1, Fig 1). The abundance of each beetle species collected varied considerably, with Cryphalini sp. 1 and Hapalogenius fuscipennis the most abundant overall taxa. Liparthrum sp. 1 was also fairly abundant, but very low numbers of Scolytoplatypus fasciatus were recorded. Cryphalini sp. 1, H. fuscipennis and Liparthrum sp. 1 constructed their galleries in the cambium/inner bark (Fig 1), while $S$. fasciatus bore straight into the sapwood of its host. Liparthrum sp. 1 seemed to prefer smaller branches, but was also commonly found inhibiting only the outer bark layers of larger branches. All species were found to share the same host plant individual with at least one other scolytine beetle at some stage during the course of the study period.

Each beetle species had a distinct gallery system (Fig 1). Parental galleries of Cryphalini sp. 1 are short and slightly thicker than those of $H$. fuscipennis and Liparthrum sp. 1 (when constructing galleries in smaller branches) and orientated horizontally (against the grain of the vascular tissue). Its larval galleries radiate at right angles from these parental galleries, extending parallel to the grain of the tree (vascular tissue). Hapalogenius fuscipennis constructs linear parental galleries that extend parallel to the grain of the host tree. Larval galleries expand at right angles from parental galleries, perpendicular to the vascular tissue. Liparthrum sp. 1 makes small parental galleries with larval galleries also diverging at right angles from these. It forms the narrowest larval galleries of the three bark beetle taxa. Scolytoplatypus fasciatus bores deep into the wood of host trees. Each parental gallery excavated $(n=3)$ contained a pair of adults.

At HPNBG, Cryphalini sp. 1, H. fuscipennis and S. fasciatus often occupied the same individual trees. At all study sites, except at Jonkershoek, Cryphalini sp. 1 and $H$. fuscipennis were often collected from the same individual tree, with their galleries constructed in close proximity to one another and often merging (Fig 1). In HPNBG, Table Mountain, SMNR and Knysna, Cryphalini sp. 1, H. fuscipennis and Liparthrum sp. 1 were often collected from the same individual trees. 


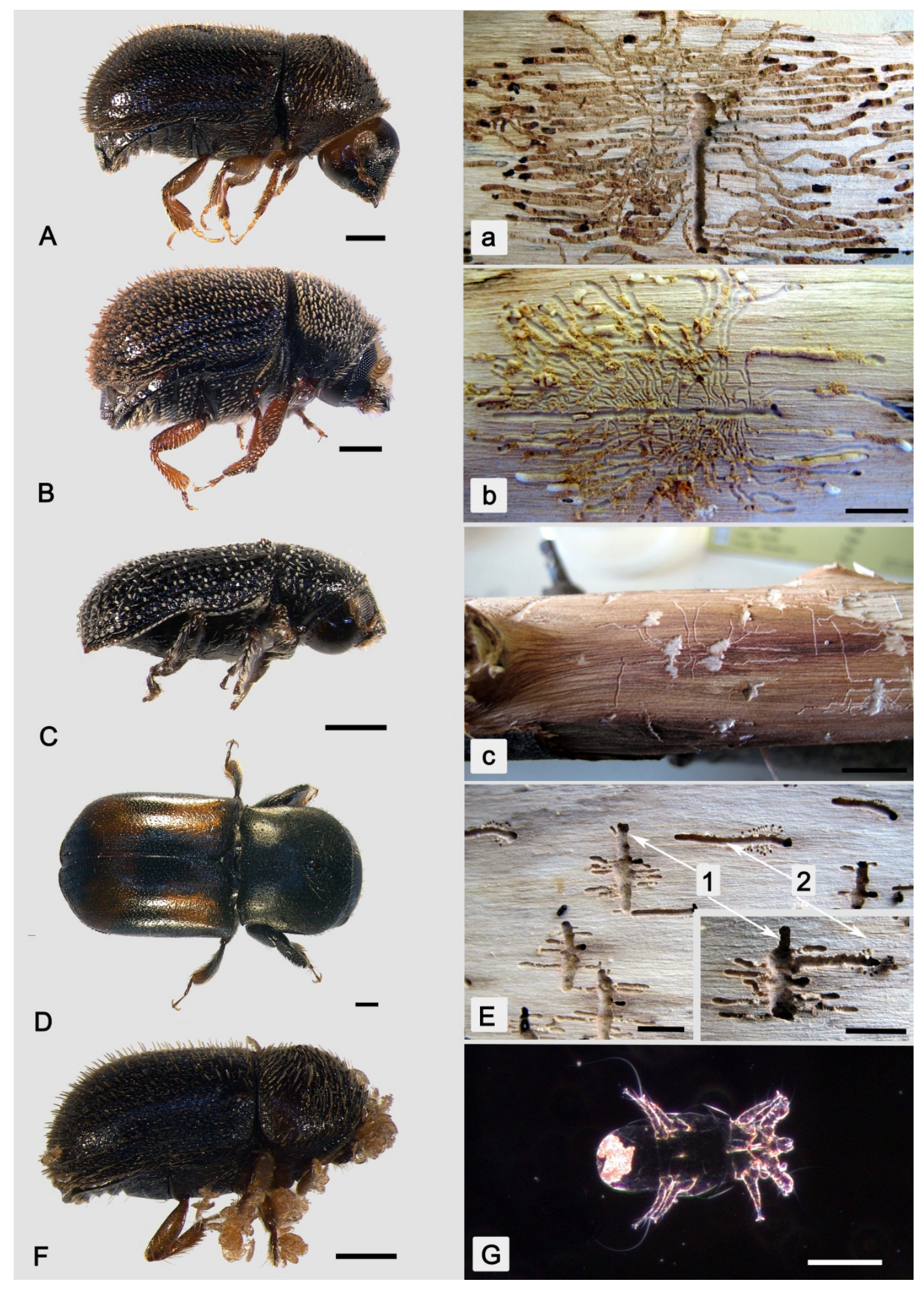

Fig 1 - Scolytinae beetles (in capital letters), their gallery systems (in non-capital letters) and phoretic mites associated with dead and dying Virgilia trees in the CFR. (A, a) Cryphalini sp. 1; (B, b) Hapalogenius fuscipennis; (C, c) Liparthrum sp. 1; (D) Scolytoplatypus fasciatus; (E) Merging gallery systems of neighbouring Cryphalini sp. 1 (1) and Hapalogenius fuscipennis (2); (F) Elattoma sp. 1 mites phoretic on Cryphalini sp. 1; (G) Light micrograph of Elattoma sp. 1. Scale bars: A-D and F $=0.25 \mathrm{~mm}, \mathrm{a}-\mathrm{c}$ and $\mathrm{E}=10$ $\mathrm{mm}, \mathrm{G}=60 \mu \mathrm{m}$. 


\subsection{Phoretic mites}

Beetles started to emerge from branches in emergence cages during week four, and carried only a few phoretic mites at that time. Cryphalini sp. 1 and $H$. fuscipennis commonly carried a single mite species (Pygmephoridae: Elattoma Mahunka, Fig 1) at all sites included in this study. The numbers of mites per individual beetle varied between zero and 217. Liparthrum sp. 1 never carried phoretic mites. Scolytoplatypus fasciatus was very rarely encountered, and phoretic mites were not usually seen on it. However, in one instance (during week six after collection) 217 individuals of the same Elattoma species were counted from a single individual. This represented the highest number of phoretic mites on any Scolytinae beetle individual collected. During week five and six the numbers of phoretic mites per individual Cryphalini sp. 1 and H. fuscipennis beetle increased significantly (Fig 2). At week seven numerous mites were still present on emerging beetles. When brood beetles started to emerge after $c a$. five months, a few mite individuals were again present (data not presented). Comparative mite numbers did not vary significantly between Cryphalini sp. 1 and $H$. fuscipennis at any given time.

\subsection{Fungal identification}

Fungal isolates could be grouped into five morphotypes based on colony morphology and micro-morphological characteristics as described by Kolařík et al. (2004, 2007, 2008). Seventy five isolates were selected for identification using DNA sequencing of the ITS gene regions. The aligned ITS data set included 86 sequences and 528 characters of which 382 were constant, 83 were parsimony-informative and 63 variable characters were parsimonyuninformative. Parsimony analyses retrieved a consensus tree with a length of 341 steps. One of the trees resulting from parsimony analyses is presented in figure 3 as the topologies of trees resulting from parsimony analysis and Bayesian inference were similar. Both parsimony analysis and Bayesian inference of the ITS marker placed our fungal isolates into five OTU's (Fig 3) that corresponded to five morphotypes identified using micro-morphological and culture characters. Four of these grouped with previously described OTU’s; Geosmithia sp. 10, G. flava Kolař́k, Kubátová \& Pažoutová, Geosmithia sp. 8 and Geosmithia sp. 2 (Fig 3). The fifth OTU grouped in a strongly supported clade, distantly related to previously published 


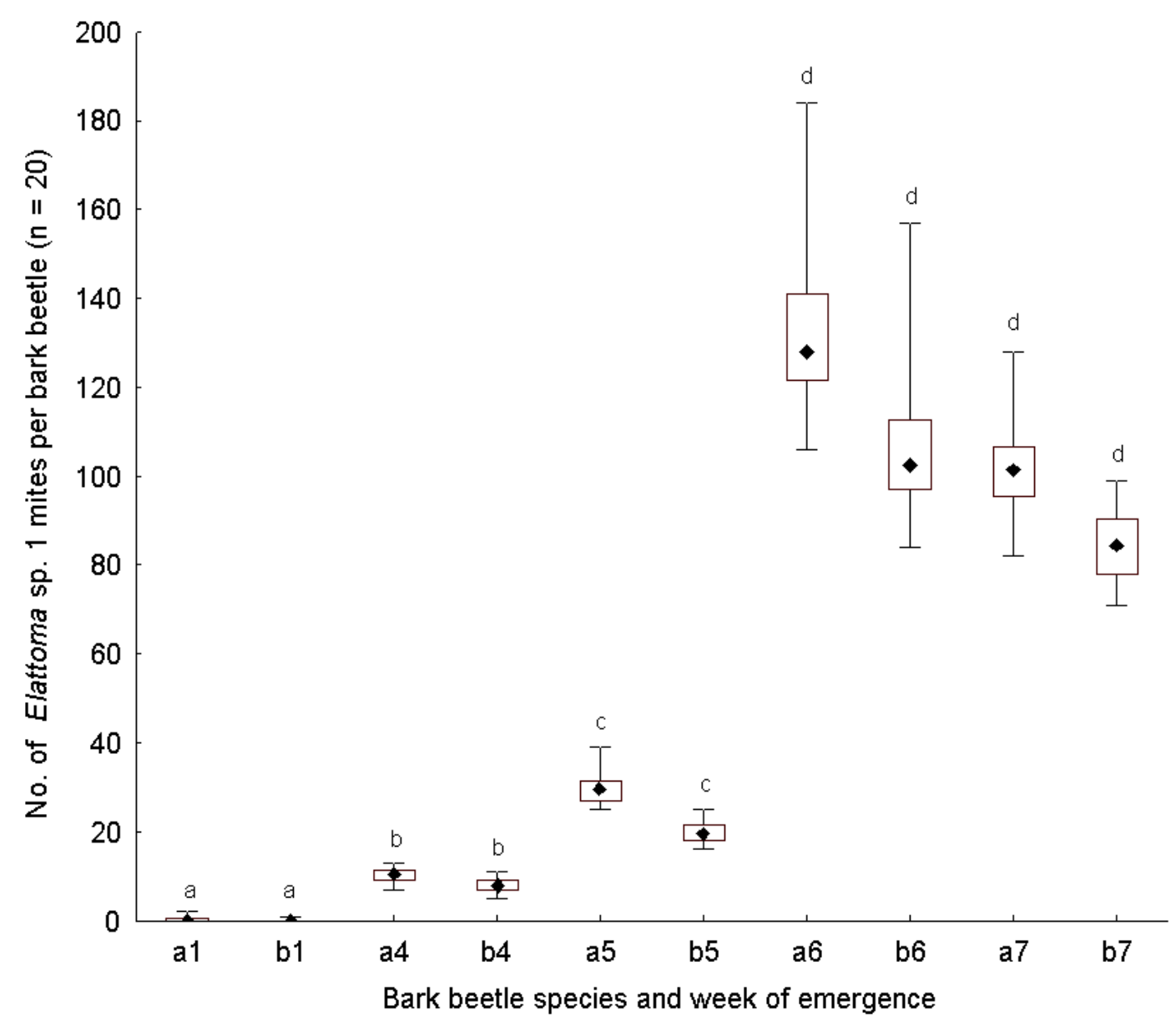

Fig 2 - Median of numbers of individuals of Elattoma sp. 1 mites (diamond symbols) phoretic on Cryphalini sp. 1 (a) and H. fuscipennis (b) as these emerged from Virgilia wood over a 7 week period (numbered from 1 to 7 on x-axis label; week 2 and 3 omitted from graph as these were the same as for week 1). Bars indicate $25 \%$ to $75 \%$ confidence and whiskers depicts data spread. Different letters above bars indicate significant differences in mite numbers encountered per individual beetle $(\mathrm{H}(\mathrm{df}=9, \mathrm{~N}=$ 200) $=92.7595 ; \mathrm{p}=0.00)$. 


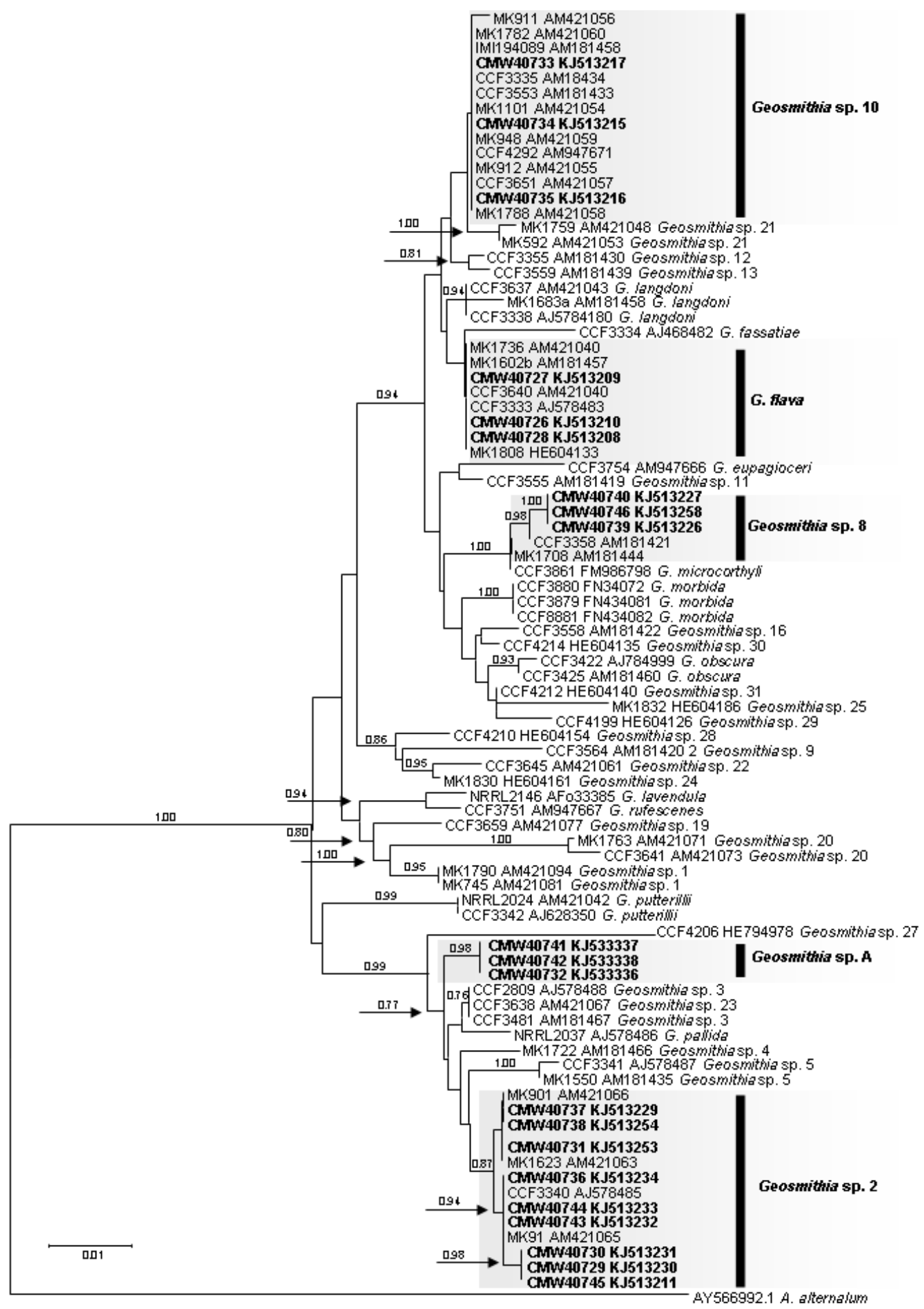

Fig 3 - One of 1871 most parsimonious trees obtained from parsimony analyses of ITS rDNA sequence data for members of the genus Geosmithia. Nodes with support values $>0.70$ for Bayesian posterior probability are provided above branches. Taxa in bold indicate isolates that originate from Virgilia trees in this study. Taxa labels for other taxa indicate isolate numbers and GenBank accession numbers respectively obtained from Kolařík \& Kirkendall (2010), Kolařík \& Jankowiak (2013) and Kolařík et al. (2004, 2005, 2007, 2008). Taxon names (species identities and numbered OTU's) followed those proposed in these previous studies. 
OTU's, and probably represents an un-described taxon, here referred to as Geosmithia sp. A. (Fig 3).

\subsection{Inter-organism associations}

Cryphalini sp. 1 and H. fuscipennis, the most abundant bark beetle species collected in this study, were found on all host taxa and at all sites except at Jonkershoek (Table 1). Jonkershoek was dominated by Liparthrum sp. 1 that was present at most sites and on both Virgilia species, but was never recorded from V. oroboides ferruginea. Scolytoplatypus fasciatus was only recorded at two sites and on $V$. oroboides (both subspecies), but this apparent host range is likely skewed by its low abundance (Table 1).

Geosmithia was the only fungal taxon consistently isolated from all individuals of all four species of Scolytinae beetles. It sporulated profusely on artificial media, and was also easily observed in both the maternal and pupal galleries of Cryphalini sp. $1, H$. fuscipennis and Liparthrum sp. 1. Due to shortage of material we were unable to isolate directly from the gallery systems of $S$. fasciatus. Cryphalini sp. 1 and $H$. fuscipennis were associated with $G$. flava, Geosmithia sp. 10, Geosmithia sp. 8 and Geosmithia sp. 2 (Tables 2 and 3). Liparthrum sp. 1 was associated with G. flava, Geosmithia sp. 10 and Geosmithia sp. 2. Scolytoplatypus fasciatus was only associated with Geosmithia sp. A, and this fungus was never collected from any other Scolytinae beetle species (Tables 2 and 3). Geosmithia communities were remarkably consistent over the sampled geographical distribution range of Virgilia, with G. flava, Geosmithia sp. 10 and Geosmithia sp. 2 recorded from all localities (Tables 2 and 3). In contrast, Geosmithia sp. 8 was only recorded from HPNBG, even though it was associated with the two most abundant Scolytinae beetle species (Cryphalini sp. 1 and $H$. fuscipennis) and the widespread V. oroboides. Geosmithia sp. A was recorded from both sites where its host beetles were found (Tables 2 and 3).

All individuals of Elattoma sp. 1 mites collected from emerging beetles consistently carried Geosmithia. The Geosmithia taxa isolated from phoretic mites were always the same as those isolated from their associated beetle individuals. Mites were unable to feed or reproduce on any of the Geosmithia OTU's, and were all dead at the end of the 40 day period, including those on control plates. These mites were, however, often seen feeding on dead bark beetle larvae within galleries. 


\section{Discussion}

In this study, Virgilia trees in the CFR were found in association with three species of bark beetles that are common throughout the region and, less commonly, with one species of ambrosia beetle. All beetles were only found on dead or dying Virgilia trees, weakened by storms and/or root pathogens. They were never associated with healthy trees, which suggests that all belong to the secondary group of bark beetles (or "facultative parasitic" beetles) (Raffa et al. 1993).

The beetles Cryphalini sp. 1, Hapalogenius fuscipennis and Scolytoplatypus fasciatus were associated with a single species of phoretic mite (Elattoma sp. 1). This mite genus is well known as a bark beetle associate in other parts of the world (e.g., Klepzig et al. 2001; Moser et al. 2005), and is considered to include truly phoretic mites, as they have lost some larval stages normal to non-phoretic taxa (Moser et al. 2005). Liparthrum sp. 1 was free of mites, probably because it was so much smaller than the other beetle taxa collected. Similar to what was documented in other systems (Lombardero et al. 2000), there appears to be a synchronization of beetle and mite life histories and emergence times on Virgilia. Very few phoretic mites were observed on beetles that still occupied their tunnels. However, after four weeks, when beetles started to emerge from tunnels, the number of phoretic mites significantly increased over time.

The genus Elattoma includes members that are fungivorous (Klepzig et al. 2001) and/or parasitoids (Moser et al. 1971), but only the biology of E. bennetti has been well studied (Hofstetter \& Moser 2014). As the females of this species feed on fungi they become massively swollen with developing larvae inside. The females rupture, releasing phoretic adult mites (Hofstetter \& Moser 2014). In the present study, Elattoma sp. 1 was unable to feed and reproduce on the various Geosmithia species that it was commonly associated with even though it was also the dominant taxon found in beetle galleries. We also did not observe massively swollen females such as were described for $E$. bennetti within beetle galleries. This suggests a commensalistic association between the mites and fungi in this system, as the Geosmithia species appear to afford no specific benefit for the mites, while the fungus benefits by being transported to new hosts. Interestingly, Elattoma sp. 1 individuals were often observed to feed on dead beetle larvae in larval tunnels. It is unknown if the mites were responsible for killing the larvae, but if not the mites may perform a "cleaning service”, ridding galleries of corpses and potentially detrimental microbes. 
As with Elattoma sp. 1, all beetle species collected in this study were associated with various species of Geosmithia. These fungi are well known as associates of phloeophagous beetles in many parts of the world (Belhoucine et al. 2011; Čizkova et al. 2005; Kolařík \& Jankowiak 2013; Kolařík \& Kirkendall 2010; Kolařík et al. 2004, 2007, 2008, 2011; Six et al. 2009; Tisserat et al. 2009), but has not yet been demonstrated as common associates of Scolytinae beetles in South Africa. Interestingly, not a single individual of any Scolytinae beetle encountered in this study was free of Geosmithia, suggesting a strong association between these two organism groups. This strong association is becoming increasingly apparent globally (Hulcr \& Dunn 2011; Kolařík \& Jankowiak 2013; Kolařík \& Kirkendall 2010; Kolař́k et al. 2004, 2005, 2007, 2008), and may include a mutualistic association if it is proven that the fungus plays a role in beetle nutrition. In the case of Virgilia species, the beetles only colonise recently dead and dying Virgilia trees of poor nutritional quality (Raffa et al. 1993), and ingestion of the fungi may have a direct nutritional advantage to the beetles, as suggested by Kolarik et al. (2008) and Kolař́k \& Kirkendall (2010).

The genus Geosmithia currently contains 31 recorded species with only 11 described to date, most of which are associated with phloeophagous beetles (Hulcr \& Dunn 2011; Kolařík \& Jankowiak 2013; Kolařík \& Kirkendall 2010; Kolařík et al. 2004, 2005, 2007, 2008). In the present study we recorded five distinct OTU's of Geosmithia based on morphological, culture and molecular characterisations. Four of these were closely related to previously recorded taxa, and included Geosmithia sp. 10, Geosmithia sp. 8, Geosmithia sp. 2 and G. flava (Kolařík \& Jankowiak 2013). Geosmithia sp. 10, Geosmithia sp. 2 and G. flava are known from various bark beetles from temperate Europe and the Mediterranean area, and from a wide range of host trees (Kolarik et al. 2007). Geosmithia sp. 8 is known from Scolytus intricatus in Quercus trees in Bulgaria, Slovakia and the Czech Republic (Kolarik et al. 2008).

Currently, the identification of Geosmithia species based on DNA sequence data relies on sequencing of the ITS 1 and 2, including the 5.8S gene region of the nuclear encoded ribosomal DNA. It is important to note that ITS rDNA data is not very diagnostic of many species of Geosmithia (Kolařík \& Kirkendall 2010; Kolařík \& Jankowiak 2013; Kolařík et al. 2011), and alternative markers should be used in future studies for clear species delimitations in this genus. It is, therefore, likely that Geosmithia sp. 10, Geosmithia sp. 8 and Geosmithia sp. 2 identified in this study represent undescribed taxa that are distinct from these formerly identified species. 
Scolytoplatypus fasciatus and its phoretic mites were exclusively associated with Geosmithia sp. A, and this fungus was not isolated from any other Scolytinae beetle. It seems to be closely related to the G. pallida species complex, but can be distinguished from these taxa by its brownish to greyish colour during sporulation. This character is also present in the closely related Geosmithia sp. 27 that is associated with Pityogenes bidentatus from Pinaceae in Poland (Kolařík \& Jankowiak 2013). As S. fasciatus is an ambrosia beetle, Geosmithia sp. A may play a role in its nutrition. Morphological characters suggesting that this fungus may be ambrosial include the formation of dense palisades of hyphae, the production of large, solitary, globular spores, and the presence of a short-lived yeast like phase after conidial germination (Kolařík \& Kirkendall 2010). Like G. rufescens, Geosmithia sp. A, therefore, seems to possess ambrosial states intermediate of the usual adaptations (Kolařík \& Kirkendall 2010).

Bark and ambrosia beetles and their associated Geosmithia species were not specific towards any particular Virgilia taxon. Geographical distance between sites surveyed did not seem to affect the association as the same Geosmithia communities were constantly isolated from the same Scolytinae beetle species at the near extreme ends of our sampling area (ca. $600 \mathrm{~km}$ apart). Our results, therefore, support those of Kolařík et al. (2008, 2013) who found similar Geosmithia communities from Scolytinae beetles that shared similar host plants (same host genus or family). The maintenance of these constant Geosmithia communities over large geographical ranges further suggests strong symbiotic interactions between these taxa. Geosmithia sp. 10, Geosmithia sp. 2 and G. flava were consistently associated with Cryphalini sp. 1, H. fuscipennis and Liparthrum sp. 1. These beetles often co-inhabited the same logs, and we often observed galleries of Cryphalini sp. 1 and H. fuscipennis to overlap, with the beetles moving around galleries of neighbouring co-existing taxa. This would facilitate fungal contact with other beetle individuals and taxa, rendering it unsurprising that the communities strongly overlap. The strong overlap between the Geosmithia communities of these beetles and those of Liparthrum sp. 1 is probably the result of construction of galleries in the outer bark of Virgilia by the latter, directly above the gallery systems of the former species which are constructed in the phloem. The close proximity of these gallery systems will easily allow the fungus to grow from one gallery system into an adjacent one. The only anomaly for this phenomenon of shared Geosmithia communities and associated beetles was in the association between S. fasciatus and Geosmithia sp. A. Scolytoplatypus fasciatus occupies an isolated niche (deep within wood), that probably does not allow it to come into frequent contact with the other Geosmithia spp. from other co-occurring beetles. 
The frequent isolation of Geosmithia sp. 8 from only one site (HPNBG), but on the two most common and widespread beetle taxa collected in this study and their associated Elattoma sp. 1 mites, is intriguing. Virgilia trees have reportedly been introduced into the HPNBG when this garden was established more than 80 years ago (J. Forrester pers. com.). Since then it has become naturalised in native vegetation surrounding the gardens. Despite this, all Scolytinae beetle species and Geosmithia OTU's identified in this study from Virgilia species throughout its natural range are present at this site. It is unlikely that these beetles were introduced with the host plants as they only invade dead and dying trees, individuals that would not be transplanted normally. It is, therefore, possible that these beetle taxa may also occur on plant species other than Virgilia and, following the same logic, the Geosmithia taxa isolated from these may also be found on other trees in natural systems. It is possible that Geosmithia sp. 8 was initially only associated with a plant taxon particular to this area, but shifted host to Virgilia using bark beetles or their associated mites. Because this is a botanical garden setting, a potential host shift from non-native plants cannot be ruled out. Some evidence for polyphagy for the beetles identified in this study includes documented polyphagy in $S$. fasciatus (Schedl 1962) and the identification of Millettia grandis (Fabaceae) as a host for $H$. fuscipennis in the northern parts of South Africa (Beaver 2010). Both beetle taxa also have very wide distribution ranges that include other African countries (Beaver 2010; Schedl 1962), well past the distribution range of Virgilia species.

This study presents the first record of Geosmithia species and their association with secondary bark beetles, ambrosia beetles and phoretic mites on Virgilia trees in South Africa. We have shown that Geosmithia communities are relatively similar for co-occurring scolytine beetles, and different for those with isolated ecological niches. In addition, geographic distance is not a determining factor for Geosmithia associates of the beetles. The relationship between Scolytinae beetles, mites and fungi on Virgilia trees is complex, and may include commensualisms, parasitism and/or mutualisms. The present study will serve as platform for further scolytine beetle-Geosmithia-mite association studies in South Africa and globally.

\section{Acknowledgements}

The authors thank the DST/NRF Centre of Excellence in Tree Health Biotechnology (CHTB) for financial support and the South African National Parks Board (SANPARKS) and Western Cape Nature Conservation Board for issuing the necessary collecting permits. We are also 
grateful to Anathi Magadlela, Anicia Malebajoa, Tendai Musvuugwa and Dewidine van der Colff for assistance with field work, Jane Forrester for permission to work on trees in the Harold Porter National Botanical Garden and Kenneth Oberlander for assisting with molecular analyses. Special thanks to Richard Hofstetter, John Moser and Michail Mandelshtam for identification of the mites and beetles collected in this study.

\section{REFERENCES}

Akaike H, 1974. A new look at the statistical model identification. IEEE Transactions on Automatic Control 19: 716-723.

Avtzis DN, Bertheau C, Stauffer C, 2012. What is next in bark beetle phylogeography? Insects 3: 453-472.

Barras SJ, 1970. Antagonism between Dendroctonus frontalis and the fungus Ceratocystis minor. Annals of the Entomological Society of America 63: 1187-1190.

Beaver RA, 2010. Taxonomic notes on the afrotropical genera Hapalogenius Hagedorn, Hylesinopsis Eggers, and Rhopalopselion Hagedorn (Coleoptera, Curculionidae, Scolytinae). Zookeys 56: 157-170.

Belhoucine L, Bouhraoua RT, Meijer M, Houbraken J, Harrak MJ, Samson RA, EquihuaMartinez A, Pujade-Villar J, 2011. Mycobiota associated with Platypus cylindrus (Coleoptera: Curculionidae, Platypodidae) in cork oak stands of North West Algeria, Africa. African Journal of Microbiology Research 5: 4411-4423.

Bridges JR, 1984. A quantitative study of the yeasts and bacteria associated with laboratoryreared Dendroctonus frontalis Zimm. (Coleoptera: Scolytidae). Journal of Applied Entomology 97: 261-267.

Cardoza YJ, Moser JC, Klepzig KD, Raffa KF, 2008. Multipartite symbioses among fungi, mites, nematodes, and the spruce beetle, Dendroctonus rufipennis. Environmental Entomology 37: 956-963.

Christiansen E, Waring RH, Berryman AA, 1987. Resistance of conifers to bark beetle attack: searching for general relationships. Forest Ecology and Management 22: 89-106. 
Čizkova D, Šrutka P, Kolarik M, Kubatova A, Pazoutova S, 2005. Assessing the pathogenic effect of Fusarium, Geosmithia and Ophiostoma fungi from broad-leaved trees. Folia Microbiologica 50: 59-62.

Fraedrich SW, Harrington TC, Rabaglia RJ, Ulyshen MD, Mayfield AE, Hanula JL, Eickwort JM, Miller DR, 2008. A fungal symbiont of the redbay ambrosia beetle causes a lethal wilt in redbay and other Lauraceae in the southeastern United States. Plant Diseases 92: 215-224.

Gardes M, Bruns TD, 1993. ITS primers with enhanced specificity for basidiomycetes application to the identification of mycorrhizae and rusts. Molecular Ecology 2: 113118.

Hall T, 2005. BioEdit, biological sequence alignment editor for Win95/98/NT/2K/XP. Carlsbad, California: Ibis therapeutic.

Harrington TC, 2005. Ecology and evolution of mycophagous bark beetles and their fungal partners. In: Vega FE, Blackwell M (eds), Ecological and Evolutionary Advances in Insect-Fungal Associations. Oxford University Press, pp. 257-291.

Harrington TC, Fraedrich SW, Aghayeva DN, 2008. Raffaelea lauricola, a new ambrosia beetle symbiont and pathogen on the Lauraceae. Mycotaxon 104: 399-404.

Harrington TC, Zambino PJ, 1990. Ceratocystiopsis ranaculosis not Ceratocystis minor var. barrasii is the mycangial fungus of the southern pine beetle. Mycotaxon 38: 103-15.

Hofstetter RW, Cronin J, Klepzig KD, Moser JC, Ayres MP, 2006. Antagonisms, mutualisms and commensalisms affect outbreak dynamics of the southern pine beetle. Oecologia 147: 679-691.

Hofstetter RW, Moser JC, 2014. The role of mites in insect-fungus associations. Annual Review of Entomology 59: 537-57.

Houbraken J, Spierenburg H, Frisvad JC. 2012. Rasamsonia, a new genus comprising thermotolerant and thermophilic Talaromyces and Geosmithia species. Antonie van Leeuwenhoek 101: 403-421.

Hulcr J, Dunn RR, 2011. The sudden emergence of pathogenicity in insect-fungus symbioses threatens naive forest ecosystems. Proceedings of the Royal Society Biological Sciences 278: $2866-2873$. 
Kirisits T, 2004. Fungal associates of European bark beetles with special emphasis on the ophiostomatoid fungi. In: Lieutier F, Day KR, Battisti A, Grégoire JC, Evans H (eds), Bark and wood boring insects in living trees in Europe, a synthesis. Kluwer Academic Press, The Netherlands, pp. 1-55.

Klepzig KD, Moser JC, Lombardero MJ, Hofstetter RW, Ayres MP, 2001. Symbiosis and competition: complex interactions among beetles, fungi and mites. Symbiosis 30: 83-96.

Kolařík M, Freeland E, Utley C, Tisserat N, 2011. Geosmithia morbida sp nov., a new phytopathogenic species living in symbiosis with the walnut twig beetle (Pityophthorus juglandis) on Juglans in USA. Mycologia 103: 325-332.

Kolařík M, Jancowiac R, 2013. Vector affinity and diversity of Geosmithia fungi living on subcortical insects inhabiting Pinaceae species in Central and Northeastern Europe. Microbial Ecology 66: 682-700.

Kolařík M, Kirkendall LR, 2010. Evidence for a new lineage of primary ambrosia fungi in Geosmithia Pitt (Ascomycota: Hypocreales). Fungal Biology 114: 676-689.

Kolařík M, Kostovčík M, Pažoutová S, 2007. Host range and diversity of the genus Geosmithia (Ascomycota: Hypocreales) living in association with bark beetles in the Mediterranean area. Mycological Research 111: 1298-1310.

Kolařík M, Kubátová A, Cepicka I, Pazoutova S, Srutka P, 2005. A complex of three new white-spored, sympatric, and host range limited Geosmithia species. Mycological Research 109: 1323-1336.

Kolařík M, Kubátová A, Hulcr J, Pažoutová S, 2008. Geosmithia fungi are highly diverse and consistent bark beetle associates: Evidence from their community structure in temperate Europe. Microbial Ecology 55: 65-80.

Kolařík M, Kubátová A, Pažoutová S, Srutka P, 2004. Morphological and molecular characterisation of Geosmithia putterillii, G. pallida comb. nov. and G. flava sp. nov., associated with subcorticolous insects. Mycological Research 108: 1053-1069.

Lieutier F, Yart A, Salle A, 2009. Stimulation of tree defences by Ophiostomatoid fungi can explain attack success of bark beetles on conifers. Annals of Forest Science 66: 801822. 
Linnakoski R, de Beer ZW, Niemelä P, Wingfield MJ, 2012. Associations of Coniferinfesting bark beetles and fungi in Fennoscandia. Insects 3: 200-227.

Lombardero MJ, Klepzig KD, Moser JC, Ayres M, 2000. Biology, demography and community interactions of Tarsonemus (Acarina: Tarsonemidae) mites phoretic on Dendroctonus frontalis (Coleoptera: Scolytidae). Agricultural and Forest Entomology 2: 193-2002.

Moser JC, Perry TJ, Bridges JR, Yin H-F, 1995. Ascospore dispersal of Ceratocystiopsis ranaculosus, a mycangial fungus of the southern pine beetle. Mycologia 87: 84-86.

Moser JC, Konrad H, Kiristis T, Carta LK, 2005. Phoretic mites and nematodes associates of Scolytus multistriatus pygmaeus (Coleoptera: Scolytidae) in Austria. Agricultural and Forest Entomology 7: 169-177.

Ogawa H, Yoshimura A, Sugiyama J, 1997. Polyphyletic origin of species of the anamorphic genus Geosmithia and the relationships of the cleistothecial genera: evidence from 18S, 5S, and 28S rDNA sequence analysis. Mycologia 89: 756-771.

Paine TD, Raffa KF, Harrington TC, 1997. Interactions among scolytid bark beetles, their associated fungi, and live host conifers. Annual Review of Entomology 42: 179-206.

Palgrave KC, 2002. Trees of Southern Africa, 3rd edn. Struik, Cape Town.

Palmer E, Pitman N, 1972. Trees of South Africa, Vol. 2. Balkema, Cape Town.

Price TS, Doggett C, Pye JL, Holmes TP, 1992. A history of southern pine beetle outbreaks in the south-eastern United States. The Georgia Forestry Commission, Georgia.

Posada D, 2008. jModelTest: Phylogenetic model averaging. Molecular Biology and Evolution 25: 1253-1256.

Raffa KF, Phillips TW, Salom SM, 1993. Strategies and mechanisms of host colonization by bark beetles. In: Schowalter T, Filip G (eds), Beetle-Pathogen Interactions in Conifer Forests. Academic Press, San Diego, pp. 102-128.

Ronquist FR, Huelsenbeck JP, 2003. MrBayes: Bayesian phylogenetic inference under mixed models. Bioinformatics 19: 1572-1574.

Schedl KE 1962. Scolytidae und Platypodidae Afrikas. II. Familie Scolytidae. Revista de Entomologia de Mozambique 5: 1-594. 
Shapiro SS, Wilk MB, 1965. An analysis of variance test for normality (complete samples). Biometrika 52: 591-611.

Six DL, 2003. Bark beetle-fungus symbioses. In: Bourtzis K, Miller T (eds), Insect symbioses. CRC Press, Boca Raton, Florida, pp. 96-116.

Six DL, De Beer ZW, Beaver RA, Visser L, Wingfield MJ, 2005. Exotic invasive elm bark beetle, Scolytus kirschii, detected in South Africa: research in action. South African Journal of Science 101: 229-232.

Six DL, Stone WD, de Beer ZW, Woolfolk SW, 2009. Ambrosiella beaveri, sp. nov., associated with an exotic ambrosia beetle, Xylosandrus mutilatus (Coleoptera: Curculionidae, Scolytinae), in Mississippi, USA. Antonie Van Leeuwenhoek 96: 17-29.

Six DL, Paine TD, 1998. Effects of mycangial fungi and host tree species on progeny survival and emergence of Dendroctonus ponderosae (Coleoptera: Scolytidae). Environmental Entomology 27: 1393-1401.

Six DL, Wingfield MJ, 2011. The role of phytopathogenicity in bark beetle-fungus symbioses: A challenge to the classic paradigm. Annual Review Entomology 56: 25572.

Stark RW, 1982. Generalized ecology and life cycle of bark beetles. In: Mitton JB, Sturgeon KB (eds), Bark Beetles in North American Conifers: A System for the Study of Evolutionary Biology. University of Texas Press, Austin, pp. 21-45.

Swofford DL, 2002. PAUP*: Phylogenetic Analysis Using Parsimony. (* and other methods), Version 4.0b10. Sinauer Associates, MA.

Theron, N, Roets F, Dreyer LL, Esler KJ, Ueckermann EA, 2012. A new genus and eight new species of Tydeoidea (Acari: Trombidiformes) from Protea species in South Africa. International Journal of Acarology 38: 257-273.

Thompson JD, Higgins DG, Gibson TJ, 1994. CLUSTAL W: improving the sensitivity of progressive multiple sequence alignment through sequence weighting, position-specific gap penalties and weight matrix choice. Nucleic Acids Research 22: 4673-4680.

Tisserat N, Cranshaw W, Leatherman D, Utley C, Alexander K, 2009. Black walnut mortality in Colorado caused by the walnut twig beetle and thousand cankers disease. Plant 


\section{Health Progress.}

http://entnemdept.ufl.edu/pestalert/thousand_cankers_disease_CO_0810.pdf

White TJ, Bruns T, Lee S, Taylor JW, 1990. Amplification and direct sequencing of fungal ribosomal RNA genes for phylogenetics. In: Innis MA, Gelfand DH, Sninsky JJ, White TJ (eds), PCR Protocols: A Guide to Methods and Applications. Academic Press, New York, pp. 315-322.

Whitney HS, 1982. Relationships between bark beetles and symbiotic organisms. In: Mitton JB, Sturgeon KB (eds), Bark beetles in North American Conifers. University of Texas Press, Austin, pp. 183-211.

Wood DL, 1982. The role of pheromones, kairomones, and allomones in the host selection and colonization behavior of bark beetles. Annual Review Entomology. 27: 411-46. 